\title{
EXTENDED CRITICAL SUCCESS FACTOR MODEL FOR MANAGEMENT OF MULTIPLE PROJ ECTS: AN EMPIRICAL VIEW FROM TRANSNET IN SOUTH AFRICA
}

\author{
J.M. Nethathe ${ }^{1}$, C.C. van Waveren ${ }^{2 *} \&$ K.-Y. Chan $^{3 *}$ \\ 1,2,3 Graduate School of Technology Management \\ University of Pretoria, South Africa \\ 1joseph.nethathe@transnet.net, ${ }^{2}$ corro@up.ac.za, ${ }^{3}$ alice.chan@up.ac.za
}

\begin{abstract}
Transnet Freight Rail in South Africa has faced projects delays in its multi-project environment. This study takes South Africa as representative of developing countries, and develops the Critical Success Factors (CSFs) model for multiple projects success, with the goal of expanding the conventional model by adding the demographic characteristics of the business units involved in the multiple projects. The empirical results showing the greatest number of success factors are people-related, with the focus on team selection and team commitment. Two demographic characteristics are of importance when managing multiple projects: the size of the business unit, and the employees' project experience.
\end{abstract}

\section{OPSOMMING}

Transnet, ' $n$ spoorvragentiteit in Suid-Afrika, ondervind gereeld projekvertragings in hul multi-projekomgewing. Suid-Afrika, as ' $n$ voorbeeld van ontwikkelende lande, word in die studie gebruik en hierdie studie ontwikkel ' $n$ reeks suksesfaktore vir 'n multi-projekomgewing deur ' $\mathrm{n}$ bestaande konvensionele model aan te pas om ook die demografiese eienskappe van die verskillende besigheidseenhede betrokke in die organisasie te inkorporeer. Die resultaat van die studie wys dat die grootste aantal suksesfaktore mensgeörienteerd is, met die fokus op die samestelling en toewyding van die betrokke projekspanne. Twee demografiese eienskape is belangrik by die bestuur van multi-projekte, naamlik die grootte van die besigheidseenheid asook projekondervinding van die werknemers.

\footnotetext{
${ }^{1}$ The author was enrolled for an M Eng (Engineering Management) degree in the Graduate School of Technology Management, University of Pretoria.

${ }^{*}$ Corresponding authors
} 


\section{INTRODUCTION}

For a long time, the factors defining a successful project have been determined by researchers. This has led to an abundant list of variables [1]. However, project success factors are not universal to all projects, and thus there should be different factors for different kinds of projects [2]. Multiple projects are unique: several projects are "accomplished side by side while drawing resources from a common resource pool" - that is, "the projects are integrated into the management control and reporting system of some common resource pool owner" [3]. Steyn et al. [4] state that most organisations experience late delivery on their projects due to overloaded technical staff working on several projects at the same time. Certain challenges or problems for organisations running multiple projects are identified in the literature. For example: the allocation of resources between simultaneous projects [3]; organisational structure and control [5]; communications [6]; and lacking commitment, and having unclear roles and responsibilities [7].

The problems experienced by most organisations are also experienced by Transnet Freight Rail's (TFR) Technology Management Team (TMT), which is in charge of initiating research and development (R\&D) projects. There are two types of $R \& D$ projects for which TMT is responsible: minor projects, arising from customers' requests; and strategic projects, initiated by senior executives within TRF. The team has a small staff, who have to work with different TFR departments to manage multiple projects; and as a result, projects tend to take longer, leading to delays. This problem is common to many organisations when they experience overload from working on multiple projects concurrently. In large organisations with a single R\&D department and a limited number of technical staff, this phenomenon is especially prevalent. Like in many organisations' $R \& D$ teams, require critical success factors (CSFs) in order to:

- $\quad$ find a model that enables the appropriate allocation of limited resources;

- help top management to determine where management attention should be directed.

This research has pointed to the need to identify a combination of CSFs if TMT is to run multiple R\&D projects successfully. Thus the aim of this study is to develop a CSFs model for multiple R\&D projects within TFR. Moreover, since TMT works with many other TFR departments, participants may have their own viewpoint about the criticality of the identified factors. This phenomenon is in line with Abdullan and Vicridge's description of a multiple projects environment, which "lies at the intersection between two different worlds, external and internal, with often conflicting expectations of the projects, different expertise and knowledge, or even different views on the criteria for a successful project" [8]. Therefore another dimension for a CSFs model is suggested in this study: demographic characteristics. This may help to identify a focus on certain types of demographic characteristics relating to the project participants.

The remainder of this paper is structured as follows. Section 2 gives a brief review of the two main concepts: the multi-project environment, and critical success factors. This section also reviews past literature that identifies project success factors so that a framework for this study can be developed. Section 3 describes the research methodology that was used, and how the data was collected. Section 4 describes the results of a survey done within Transnet Freight Rail. The discussion in this section includes identification of critical success factors for multiple project success, and the possibility of extending this model by including a demographic dimension. Section 5 offers some concluding remarks.

\section{THEORETICAL REVIEW AND FRAMEWORK}

Two concepts - the multiple project environment, and critical success factors (CSFs) are reviewed briefly in this section, followed by discussions of success factors in the project management literature. Finally, the research model is presented for empirical analysis. 


\subsection{Multi-project environment}

In a multiple project environment, individuals can be responsible for work on various different life cycle phases of different projects on a part-time basis. That is, they are not allocated full-time to a particular project, and each project is in a different life cycle phase [9]. Recent literature has also indicated that most organisations experience late deliveries on their projects due to their technical staff being overloaded by working on several projects at the same time (Steyn et al. [4]). Steyn et al. also give two reasons for the problems experienced in multiple projects:

- Many organisations and individuals take on too many projects at the same time without prioritising either the projects themselves or the activities within the projects.

- The workload of each project is not visible, and this makes it impossible to assess the workload of an individual across the various projects he or she is working on.

Furthermore, Nicolas and Steyn [10] highlighted the dependency of resources by noting that multiple projects may be independent (that is, they have separate goals or clients), but are dependent on the common resource pool of the organisation. Figure 1 illustrates multiple projects that run concurrently (i.e. overlapping in time), and a common resource pool that supplies all the projects. Figure 1 shows that there is a single project environment in $t_{0}$ and $t_{1}$, and after $t_{3}$. In this study, the research focus lies in the multi-project environment between $t_{1}$ and $t_{3}$. At $t_{2}$, four projects run concurrently at various life cycle phases; and this may cause serious problems with constrained resources.

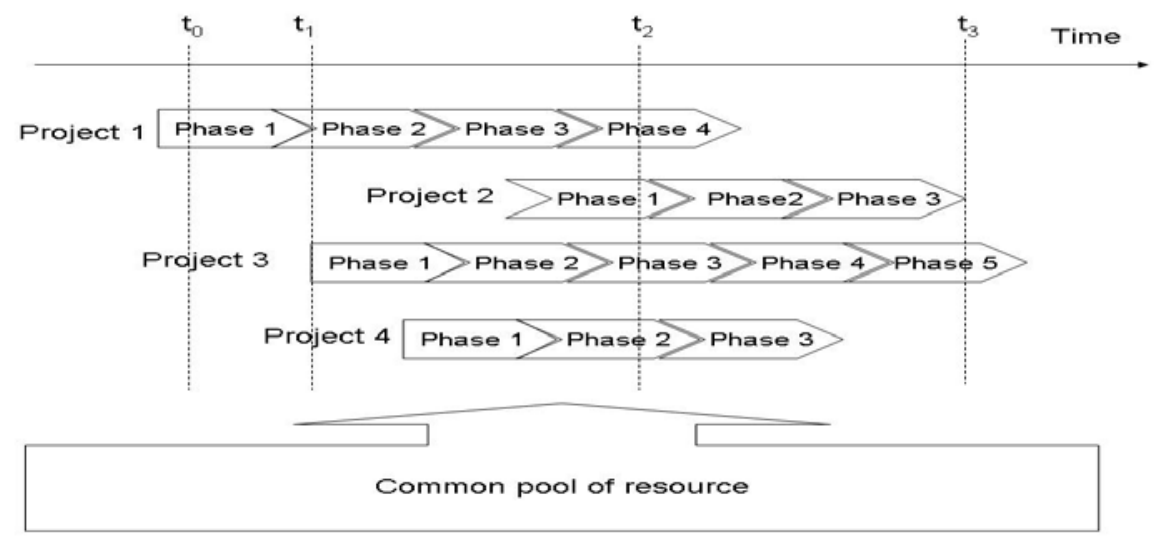

Figure 1: An illustration of multiple projects sharing a common pool of resource.

Because of resource limitations, the common problem or challenge that multiple projects face involves "determining how to allocate resources to, and set a completion time for, a new project that is added to an existing set of on-going projects" [11]. Moreover, researchers in the past have pointed to the importance of scheduling multiple projects with constrained resources $[10,12]$. In the recent literature, many techniques and tools have been developed to overcome the problem of multiple projects; examples include baseline scheduling [13], a combinatorial PSO (CPSO) algorithm [14], and the hybrid genetic algorithm with fuzzy logic controller (flc-hGA) [15]. There seems to be little research that investigates the factors that may overcome the problem of multiple projects. In other words, even though critical success factors as a framework for managing an individual project are often reported in the literature, a framework has not been developed for multiple R\&D projects; a gap therefore remains within the literature.

\subsection{Definition of 'project success' in a multi-project environment}

Project success can be considered in two dimensions: 'project success' and 'project management success'. According to De Wit [16], project success is measured against the overall objectives of the project, whereas project management success is measured against the widespread and traditional measures of performance against cost, time, and quality. As 
illustrated in the above section, in a multi-project environment multiple projects have their own objectives. Thus the measurement of multiple project success is associated with the objectives of all projects within the company. The definition of 'project success' in a multiproject environment in this study of Transnet uses the concepts of both project success and project management success. Multiple projects are considered to be successful if they meet the objectives of Transnet Freight Rail projects, as well as being managed on time, within budget, and to quality specifications.

\subsection{Critical success factor approach}

The idea of success factors was introduced by Daniel's [17] report entitled 'Management information crisis', which said that success factors differ from company to company, and that each industry has a genetic set of success factors. In 1979 the concept of critical success factors (CSF) was popularised by Rockart [18], who defined the term 'critical success factors' (CSF) in two parts:

a) CSFs are areas of activity that should receive constant and careful attention from management;

b) CSFs are the limited number of areas in which results, if they are satisfactory, will ensure successful competitive performance by the organisation. They are the few key areas where things must go right for the business to flourish. If results in these areas are not adequate, the organisation's efforts for the period will be less than desired.

Moreover, Rockart's study suggested that there should be a small number of CSFs for any given manager - preferably ten or fewer. Critical success factors are specific to an organisation, although some may be generalisable. Many organisations have used the CSFs approach as a framework for strategic planning [19]. To ascertain CSFs, Rockart [18] proposed a two-step interview method. First there is a round of open interviews, where managers are asked about their views on the CSFs relevant to the business. On the basis of these, a preliminary list of factors is compiled that, in a second round, are rated for their importance.

\subsection{Development of CSFs research framework}

The search for CSFs began in 1960 when Daniel [17] initiated the concept. In the literature, critical success factor (CSF) models have been studied for various types of projects in different domains. For example, critical success factors were identified by Tishler et al. [20] in defence development projects. More recently, Aksorn and Hadikusumo [21] used a CSF model to identify key factors that influence safety programme performance in Thai construction projects; Chow and Cao [22] surveyed critical success factors in agile software projects; and Zhao et al. [23] compared CSF models for two Build-Operate-Transfer (BOT) electric power projects. Numerous lists of success factors have been identified in the past; but recently the flow of research publications identifying new sets of project success factors "has slowed but reference to and use of the concept has not diminished" [24]. The purpose of this section is to look into publications that have reported project critical success factors.

Recent studies by White \& Fortune have reviewed a total of 80 publications on project success factors during 2002 [25] and 2006 [24]. In 2002 they identified a list of 19 critical factors for project success from 14 publications; and another five were added by their respondents in the survey, giving a total of 24 CSFs. In 2006 they identified a further 27 critical success factors across 63 reviewed publications. However, some of the previous 24 CSFs overlapped with the 27 CSFs identified later. A new list of 30 CSFs, combining the two studies, is given in Table 1. Dvir et al. [2] explored project success factors, but with a focus on managerial factors. Based on their previous work [26], they classified 26 factors into four groups (Table 2).

It is interesting to note the difference between the two lists. Dvir et al. classified the factors they identified; White \& Fortune did not. As mentioned earlier in the critical success factor literature, CSFs are specific to an organisation; so not all the factors found in the literature may apply in this study. 


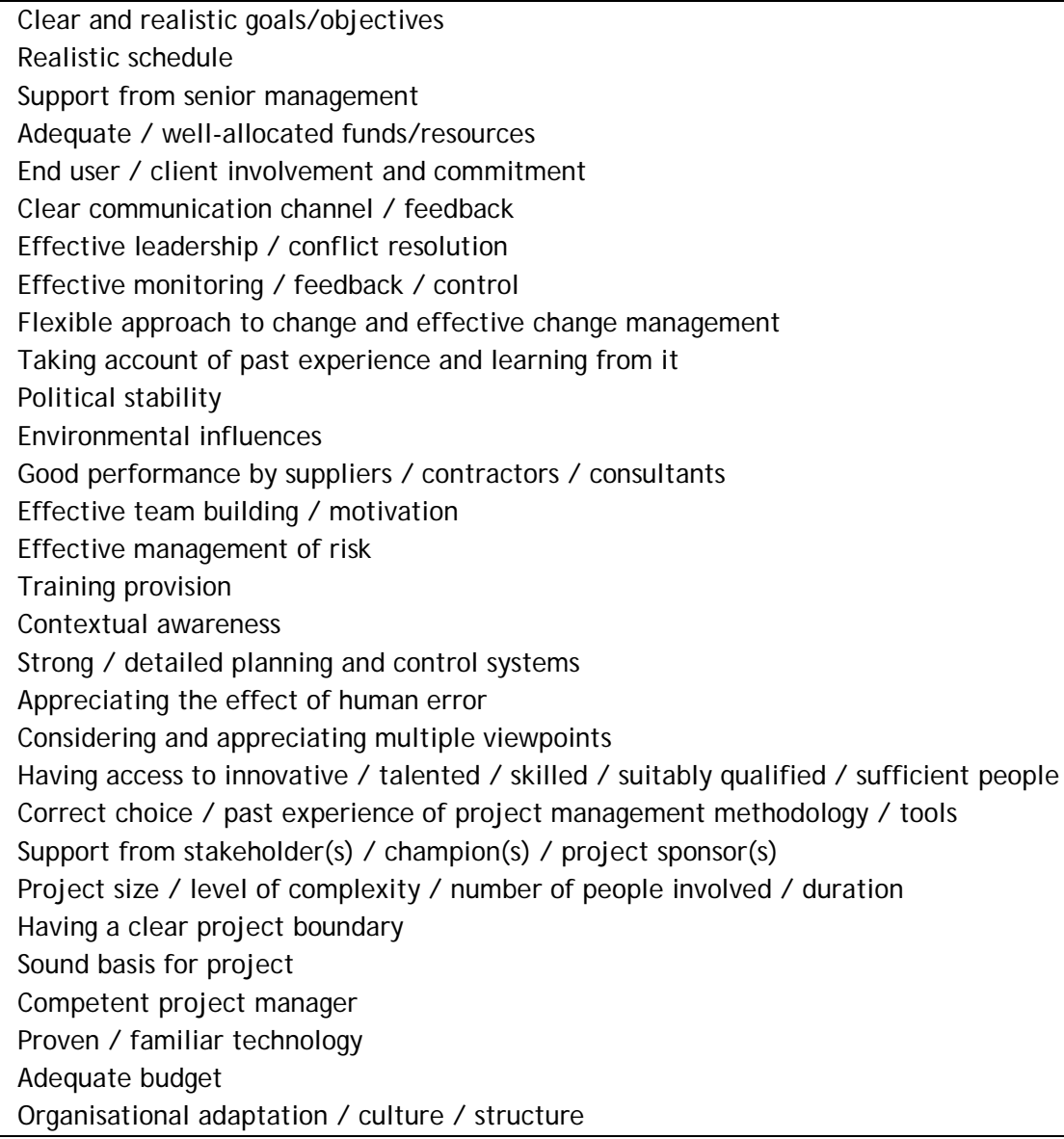

Table 1: Project critical success factors (adapted from White \& Fortune [25], Fortune \& White [24])

However, the study by Dvir el al. has led the authors to look into the literature where other authors have identified or grouped their sets of critical success factors. The identified groups may serve as a guideline for the development of a research framework for this study.

Belassi \& Tukel [27] also believed that the success factors listed in the earlier literature are either very general or very specific to a particular project. They proposed a new scheme that classified project success factors by identifying groups to which the critical factors belong. The new framework they proposed grouped project success factors into four areas:

- factors related to the project

- factors related to the project manager and the team members

- factors related to the organisation, and

- factors related to the external environment.

A more recent study by Chow \& Cao [22] classified project success factors into groups similar to the Belassi \& Tukel [27] model. Based on previous research publications, they identified a list of factors that covered 39 attributes. A reliability analysis was performed on all multi-item factors using Conbach's alpha method, and later a principal component factor analysis with Varimax rotation was performed on this list of factors to see if it could be reduced any further. The final results provided 12 factors, classified into five groups (Table 3). 


\begin{tabular}{|c|c|}
\hline Groups & Project success factors \\
\hline \multirow{6}{*}{$\begin{array}{l}\text { Factors related to: } \\
\text { Project initiation and pre-contract activities }\end{array}$} & Definition of operational need \\
\hline & Urgency of need \\
\hline & Alternative solutions \\
\hline & Definition of technical and operational specs \\
\hline & Pre-contract activities \\
\hline & Customer follow-up team \\
\hline \multirow{7}{*}{$\begin{array}{l}\text { Factors related to: } \\
\text { Project preparation and design policy, } \\
\text { technological infrastructure and design } \\
\text { methods }\end{array}$} & Pre-project preparation \\
\hline & Managerial policy \\
\hline & Technological infrastructure \\
\hline & Prototypes \\
\hline & Number of design cycles \\
\hline & Design freeze timing \\
\hline & Design considerations \\
\hline \multirow{5}{*}{$\begin{array}{l}\text { Factors related to: } \\
\text { Planning and control processes }\end{array}$} & Project milestones \\
\hline & Project control \\
\hline & Effectiveness of project control \\
\hline & Budget management \\
\hline & Discussions and reports \\
\hline \multirow{8}{*}{$\begin{array}{l}\text { Factors related to: } \\
\text { Organisational and managerial environment }\end{array}$} & Organisational environment \\
\hline & Manager style \\
\hline & Communication style \\
\hline & Flexibility in management \\
\hline & Delegation of authority \\
\hline & Organisational learning \\
\hline & Team characteristics \\
\hline & Manager qualifications \\
\hline
\end{tabular}

Table 2: Project success factors (adapted from Dvir et al. [2])

\begin{tabular}{|l|l|}
\hline Groups & Project CSFs \\
\hline \multirow{3}{*}{ Organisational factors } & Management commitment \\
\cline { 2 - 2 } & Organisational environment \\
\cline { 2 - 2 } & Team environment \\
\hline \multirow{2}{*}{ People factors } & Team capability \\
\cline { 2 - 2 } & Customer involvement \\
\hline \multirow{2}{*}{ Process factors } & Project management process \\
\cline { 2 - 2 } & Project definition process \\
\hline \multirow{2}{*}{ Technical factors } & Technical supports \\
\cline { 2 - 2 } & Delivery Strategy \\
\hline \multirow{2}{*}{ Project factors } & Project nature \\
\cline { 2 - 2 } & Project type \\
\cline { 2 - 2 } & Project schedule \\
\hline
\end{tabular}

Table 3: Project success factors (adapted from Chow \& Cao [22])

Taking the identified project success factors and the various groups found in the literature, the authors first talked with top management of TFR about their views of possible classifications of success factors. Then, based on these detailed discussions, the authors proposed a hypothetical framework to address the research questions. This framework (Figure 2) will be used in the first round of data gathering (more details will be discussed in the next section).

\section{RESEARCH METHODOLOGY}

Balachandra [28] argues that in most organisations, project management principles are followed, yet less than $10 \%$ of projects are finished on time. This is also one of the most common problems in managing multiple projects. The purpose of this paper is to develop a critical success factor (CSF) model for multiple project management in Transnet Freight Rail (TFR), one of the largest projects-based businesses in South Africa. 


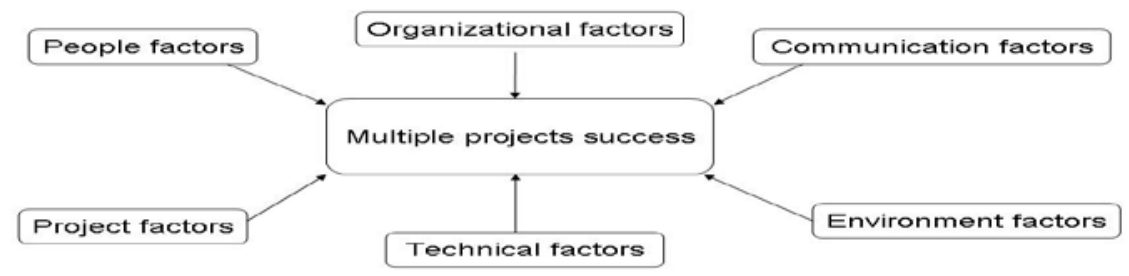

Figure 2: Factors framework for multiple projects success

\subsection{Data collection}

This research applied both qualitative and quantitative research methodologies. The study followed a two-step interview method for ascertaining CSFs (as proposed by Rockart [18]). The data was collected in two rounds. In the first round, success factors based on the literature review in Section 2.4 were discussed with project managers, senior engineers, and maintenance engineers in TFR. These discussions served as a pre-test to develop a list of success factors that TFR employees might perceive as critical to the organisation. Questionnaires were developed from the refined list of success factors. In the second round, the questionnaires were distributed to the TFR employees in various TFR units. The design of the questionnaire will be explained further below.

Because the population of interest was TFR, the findings are specific to it, and will not be generalised for any other organisation. The authors wished to have an effective sample size of at least 200 respondents to give an accurate picture of the perceptions of TFR employees about critical success factors that their environment required. After the second round, 400 questionnaires were distributed, of which 250 were returned (a response rate of $62.5 \%$ for analysis using SPSS statistical software.

\subsection{Questionnaire design and statistical methods}

There were two parts to the questionnaire design:

Part 1: Demographic characteristics (Q1 Q4), and

Part 2: Criticality of each factor with regard to the success of multiple projects (Q5 Q10).

As mentioned earlier in this paper, the main purpose of the research was to develop a CSF model for multiple projects. By calculating the means of the criticality of the factors rated by the respondents, the top 10 critical success factors were listed and a conventional CSF model for multiple projects in TFR was developed. In order to extend the conventional CSF model, the first part of the questionnaire was used to include the demographic dimension, which was then added to the conventional CSF model in two steps. First, from the frequency counts of the sub-questions in Q1 Q4, the authors identified possible independent groups amongst the business units based on their characteristics:

- Business unit type

- Business unit size (number of employees)

- Employee's years of experience as a member or leader in a project team, and

- Sources used to initiate projects.

Second, an independent samples t-test was used to determine whether there were any significant differences in the ratings of the criticality of success factors between the identified groups. If a significant difference was found in the ratings of a specific critical factor, the critical factor had to take the corresponding demographic characteristic into account. The research methodology is summarised in a flow diagram (Figure 3). 


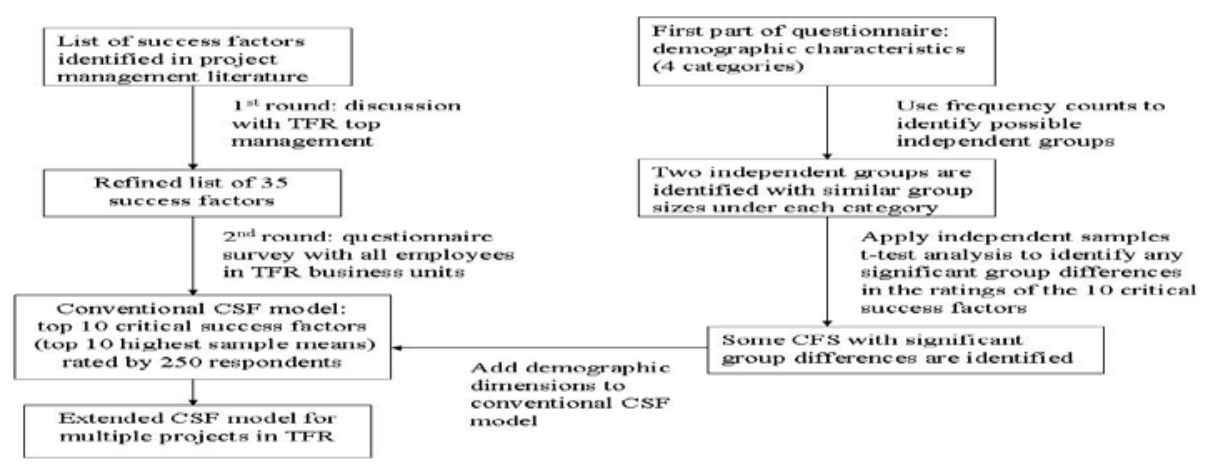

Figure 3: Research methodology flow diagram

\section{EMPIRICAL RESULTS}

In this section, the descriptive analysis applied to the data from both sections of the questionnaire is discussed. This includes the demographic characteristics (to identify groups) and the success factors of multiple projects (to establish CSF model). Once the groups were identified, independent samples t-tests were used to explore the group means with significant differences (and thus the possibility of expanding the model by adding the demographic dimension). In the last part of this section, a complete extended version of a CSF model for multiple projects in the TFR business environment is presented.

\subsection{Descriptive analysis: characteristic of business unit}

Frequency counts of the demographic characteristics are shown in Table 4 . The results of the frequency counts will further identify two possible independent groups with equal group sizes. Evaluating the business unit type category in Table 4, the engineering business units have $55 \%$ of the sample populations and the rest of business units (i.e. manufacturing, information technology, and construction) the remaining 45\% Two independent groups with similar group sizes were identified in the sample populations as 'engineering' (denoted as Group 1) and 'non-engineering' (denoted as Group 0) business units. Similarly, two independent groups with similar group sizes were identified for the other three categories. The results are summarised in Table 5. These groups will be used in the independent samples t-test in order to compare the mean ratings of success factors between these groups.

\begin{tabular}{|l|l|c|}
\hline \multicolumn{2}{|c|}{ Demographic characteristics } \\
\hline \multirow{4}{*}{ Type of business unit } & Frequency counts (\%) \\
\hline \multirow{4}{*}{$\begin{array}{l}\text { Size of business unit } \\
\text { (number of employee) }\end{array}$} & Engineering & 55 \\
\cline { 2 - 3 } & Manufacturing & 21 \\
\cline { 2 - 3 } & Information Technology & 13 \\
\cline { 2 - 3 } & Construction & 1 \\
\cline { 2 - 3 } & Less than 50 & 0 \\
\cline { 2 - 3 } & Between 50 and 99 & 2 \\
\cline { 2 - 3 } $\begin{array}{l}\text { Employee experience } \\
\text { (number of years of } \\
\text { project experience) }\end{array}$ & Between 100 and 900 and 9,999 & 47 \\
\cline { 2 - 3 } & 10,000 and more & 26 \\
\cline { 2 - 3 } & Less than 5 & 25 \\
\cline { 2 - 3 } & Between 6 and 10 & 24 \\
\cline { 2 - 3 } $\begin{array}{l}\text { Source used to initiate } \\
\text { projects }\end{array}$ & Between 11 and 15 16 and 20 & 29 \\
\cline { 2 - 3 } & Marketing & 17 \\
\cline { 2 - 3 } & Technical staff & 15 \\
\cline { 2 - 3 } & Top management & 15 \\
\cline { 2 - 3 } & More than one source & 36 \\
\hline
\end{tabular}

Table 4: Frequency counts of demographic characteristics 


\begin{tabular}{|l|l|l|c|}
\hline & Group code & \multicolumn{1}{|c|}{ Group description } & Frequency counts (\%) \\
\hline \multirow{2}{*}{ Type of business unit } & Group 0 & Non-engineering & 45 \\
\cline { 2 - 4 } & Group 1 & Engineering & 55 \\
\hline \multirow{2}{*}{ Size of business unit } & Group 0 & Less than 1,000 & 48.8 \\
\cline { 2 - 4 } & Group 1 & More than 1,000 & 51.2 \\
\hline Source of projects & Group 0 & Less than 10 years & 53.2 \\
\cline { 2 - 4 } & Group 1 & More than 10 years & 46.8 \\
\cline { 2 - 4 } & Group 0 & Single source & 41.2 \\
\cline { 2 - 4 } & Group 1 & Multiple sources & 58.8 \\
\hline
\end{tabular}

\section{Table 5: Independent groups identified}

\subsection{Descriptive analysis: Success factors for multiple projects}

As mentioned in the research methodology section, a questionnaires survey was used, and respondents were asked to rate the criticality of factors listed in the questionnaires to the success of multiple projects. In Table 6 , the descriptive statistics are presented for the success factors of multiple projects in TFR.

\begin{tabular}{|c|c|c|}
\hline Variables & Means & Std. dev. \\
\hline \multicolumn{3}{|l|}{ Category: Organisational factors } \\
\hline Functional manager support & 4.12 & 0.840 \\
\hline Top management review & 2.97 & 1.103 \\
\hline Top management sponsor & 3.66 & 1.063 \\
\hline Identify project source & 2.86 & 1.406 \\
\hline Flat structure & 2.49 & 1.159 \\
\hline Outsourcing & 2.61 & 1.297 \\
\hline \multicolumn{3}{|l|}{ Category: Communication factors } \\
\hline Emails & 3.85 & 0.807 \\
\hline Fax & 1.81 & 0.967 \\
\hline Telephone conference & 3.14 & 1.028 \\
\hline Monthly project review & 3.89 & 0.910 \\
\hline Website & 3.85 & 1.030 \\
\hline \multicolumn{3}{|l|}{ Category: People factors } \\
\hline Project manager technical background & 3.40 & 1.170 \\
\hline Project manager communication skills & 3.96 & 0.774 \\
\hline Project team competence & 3.94 & 0.887 \\
\hline Team commitment & 4.29 & 0.707 \\
\hline Team selection & 4.33 & 0.785 \\
\hline Team in one place & 3.25 & 1.166 \\
\hline Team in different areas & 2.70 & 1.030 \\
\hline Skills transfer to new teams & 4.06 & 0.790 \\
\hline \multicolumn{3}{|l|}{ Category: Project factors } \\
\hline Small projects & 3.09 & 0.879 \\
\hline Large projects & 3.82 & 0.950 \\
\hline Short period & 3.39 & 0.876 \\
\hline Long period & 3.18 & 0.995 \\
\hline Project uniqueness & 3.16 & 0.974 \\
\hline Urgency & 2.92 & 1.177 \\
\hline Rate of new product development & 2.76 & 1.077 \\
\hline Design review with all stakeholders & 4.10 & 0.775 \\
\hline Design review with project management \& top management & 2.50 & 1.118 \\
\hline \multicolumn{3}{|l|}{ Category: Technical factor } \\
\hline Equipment support & 2.74 & 1.255 \\
\hline \multicolumn{3}{|l|}{ Category: Environment factor } \\
\hline Politics and social involvement & 2.90 & 1.165 \\
\hline Competitor technologies & 3.28 & 1.100 \\
\hline Reliability of sub-contractors & 3.65 & 1.022 \\
\hline Knowing client needs & 3.79 & 1.134 \\
\hline Economic standing of the organisation in funding small projects & 3.19 & 0.833 \\
\hline Economic standing of the organisation in funding large projects & 4.04 & 0.767 \\
\hline
\end{tabular}

Table 6: Means and standard deviations of success factors 
In the organisational factors category, functional manager support was rated the highest. This implies that, when running multiple projects, functional managers play an important role in the organisation. In the second category (communication factors), monthly project reviews were more important than communications via email or website. In other words, when managing multiple projects, regular personal face-to-face communications are vital. In the people factors aspect, team selection is considered the most critical factor in managing successful multiple projects. This may account for the fact that multiple projects require members from various professional backgrounds; and so a proper team with the right project members is essential. Design review with all stakeholders is the most critical success factor in the project factors category. On the other hand, design reviews with project management and top management had the lowest criticality score. One way to interpret this result is that, when managing multiple projects, an overview is needed across all projects, and reviews from all stakeholders should be taken into account. Reviews only from the project management or top management may not be sufficient to control multiple projects. The equipment support factor had a score of 2.74 (out of 5), which means that its criticality is only moderate. In the environment aspect, funding of large multiple projects is an important factor. When multiple projects are large in nature, more resources are needed to ensure the successful completion of the project.

\subsection{Descriptive analysis: Critical success factors for multiple projects}

According to the literature review, there should be a small number of critical success factors (CSFs). Rockart [18] recommends 10 or fewer. By evaluating the top 10 mean values in Table 6, the CSFs model for multiple projects in the TFR business environment is developed (see Table 7).

\begin{tabular}{|c|c|c|c|c|c|}
\hline Categories & Factor name & Description of the factor & Mean & SD & $\begin{array}{l}\text { CSFs } \\
\text { Rank }\end{array}$ \\
\hline \multirow{5}{*}{ People factors } & Team selection & $\begin{array}{l}\text { Selection of an adequate team to } \\
\text { run the project }\end{array}$ & 4.33 & 0.785 & CSFs 1 \\
\hline & $\begin{array}{l}\text { Team } \\
\text { commitment }\end{array}$ & $\begin{array}{l}\text { Commitment of the project } \\
\text { manager, project team, and top } \\
\text { management to the project }\end{array}$ & 4.29 & 0.707 & CSFs 2 \\
\hline & $\begin{array}{l}\text { Skills transfer to } \\
\text { new teams }\end{array}$ & $\begin{array}{l}\text { Developing knowledge of new team } \\
\text { members in the organisation }\end{array}$ & 4.06 & 0.790 & CSFs 5 \\
\hline & $\begin{array}{l}\text { Project manager } \\
\text { communication } \\
\text { skill }\end{array}$ & $\begin{array}{l}\text { Importance of a project manager's } \\
\text { communication skills }\end{array}$ & 3.96 & 0.774 & CSFs 7 \\
\hline & $\begin{array}{l}\text { Project team } \\
\text { competence }\end{array}$ & $\begin{array}{l}\text { The competence of the project } \\
\text { leader and project team in the field } \\
\text { where the project is conducted }\end{array}$ & 3.94 & 0.887 & CSFs 8 \\
\hline \multirow{2}{*}{$\begin{array}{l}\text { Communication } \\
\text { factors }\end{array}$} & $\begin{array}{l}\text { Monthly project } \\
\text { review }\end{array}$ & Monthly review meetings & 3.89 & 0.910 & CSFs 9 \\
\hline & Emails & $\begin{array}{l}\text { Using email as a type of } \\
\text { communication during project life }\end{array}$ & 3.85 & 0.807 & $\begin{array}{c}\text { CSFs } \\
10\end{array}$ \\
\hline $\begin{array}{l}\text { Organisational } \\
\text { factors }\end{array}$ & $\begin{array}{l}\text { Functional } \\
\text { manager supports }\end{array}$ & $\begin{array}{l}\text { Encouraging functional managers' } \\
\text { support }\end{array}$ & 4.12 & 0.840 & CSFs 3 \\
\hline Project factors & $\begin{array}{l}\text { Design reviews } \\
\text { with all } \\
\text { stakeholders }\end{array}$ & $\begin{array}{l}\text { Design reviews with all stakeholders } \\
\text { involved }\end{array}$ & 4.10 & 0.775 & CSFs 4 \\
\hline $\begin{array}{l}\text { Environment } \\
\text { factors }\end{array}$ & $\begin{array}{l}\text { Large project } \\
\text { economic } \\
\text { standing }\end{array}$ & $\begin{array}{l}\text { Economic standing of the } \\
\text { organisation in funding large } \\
\text { proj ects }\end{array}$ & 4.04 & 0.767 & CSFs 6 \\
\hline
\end{tabular}

Table 7: Means and standard deviations of critical success factors

In Table 7, most CSFs fall under the people factors category. This implies that people aspects play an important role in managing multiple projects. This may account for the dynamic nature of multiple projects, where more people from various backgrounds are involved, compared with managing a single project where routines and procedures are already developed and therefore less complicated to manage. This reasoning also applies to the communication aspect, where this category has two CSFs. When more people are 
involved, regular personal and direct communication plays an important role to clarify and review complex situations in multiple projects.

\subsection{Independent samples t-test results: Expanding the CSFs model}

Table 7 shows a conventional CSFs model. In this study we explore the possibility of expanding this model by adding another dimension. Since various groups exist in the sample population (see Table 5), we examined how these groups rated the criticality of the ten CSFs differently (significant at 5\% level). Table 8 shows the independent samples t-test results for the two groups in the type of business unit category and the two groups in the size of business unit category. Table 9 shows the t-test results for groups in the employee experience and sources of project categories.

\begin{tabular}{|c|c|c|c|c|c|c|c|c|c|c|}
\hline \multirow{3}{*}{ CSF } & \multicolumn{5}{|c|}{$\begin{array}{c}\text { Type of business unit } \\
\text { Group 0: non-engineering unit } \\
\text { Group 1: engineering unit }\end{array}$} & \multicolumn{5}{|c|}{$\begin{array}{c}\text { Size of business unit } \\
\text { Group 0: less than } 1000 \text { employee } \\
\text { Group 1: more than } 1000 \text { employee }\end{array}$} \\
\hline & \multicolumn{2}{|c|}{$\begin{array}{c}\text { Group } 0 \\
(\mathrm{~N}=113)\end{array}$} & \multicolumn{2}{|c|}{$\begin{array}{c}\text { Group 1 } \\
(\mathrm{N}=137)\end{array}$} & \multirow{2}{*}{$\begin{array}{c}\text { Mean } \\
\text { difference } \text { t-test }^{a} \\
\text { p-value }\end{array}$} & \multicolumn{2}{|c|}{$\begin{array}{l}\text { Group } 0 \\
(\mathrm{~N}=122)\end{array}$} & \multicolumn{2}{|c|}{$\begin{array}{c}\text { Group 1 } \\
(\mathrm{N}=128)\end{array}$} & \multirow{2}{*}{$\begin{array}{c}\text { Mean } \\
\text { difference } \\
\text { t-test }^{a} \\
\text { p-value }^{b}\end{array}$} \\
\hline & Mean & SD & Mean & SD & & Mean & SD & Mean & SD & \\
\hline CSF1 & 4.40 & 0.819 & 4.26 & 0.753 & 0.134 & 4.34 & 0.781 & 4.31 & 0.791 & 0.026 \\
\hline CSF2 & 4.28 & 0.716 & 4.30 & 0.703 & -0.022 & 4.22 & 0.724 & 4.3 & 0.687 & -0.134 \\
\hline CSF3 & 4.02 & 0.920 & 4.21 & 0.761 & -0.194 & 3.98 & 0.870 & 4.27 & 0.789 & $-0.290^{*}$ \\
\hline CSF4 & 3.96 & 0.823 & 4.20 & 0.71 & $-0.240 *$ & 4.06 & 0.731 & 4.1 & 0.8. & -0.075 \\
\hline CSF5 & 00 & 0.865 & & 0.7 & -0.105 & 4.01 & 0.767 & 4.1 & 0.814 & -0.094 \\
\hline CSF6 & 4.10 & 0.735 & 3.99 & 0.792 & 0.113 & 4.02 & 0.745 & 4.06 & 0.790 & -0.038 \\
\hline CSF7 & 3.88 & 0.818 & 4.04 & 0.732 & -0.161 & 3.78 & 0.736 & 4.14 & 0.771 & $-0.364^{*}$ \\
\hline CSF8 & 3.99 & 0.840 & 3.90 & 0.925 & 0.088 & 3.88 & 0.888 & 4.00 & 0.885 & -0.119 \\
\hline CSF9 & 3.79 & 0.973 & 3.96 & 0.850 & -0.170 & 3.67 & 0.845 & 4.09 & 0.926 & $-0.414^{*}$ \\
\hline CSF10 & 3.94 & 0.789 & 3.77 & 0.816 & 0.165 & 3.79 & 0.787 & 3.9 & 0.824 & -0.120 \\
\hline
\end{tabular}

a. Mean difference between two groups

b. Significance at $5 \%$ level ( $p$-value $\varangle 0.05$ )

* mean difference is statistically significant at $p \varangle 0.05$

\section{Table 8: Independent t-test: Business unit type and size}

Compared with non-engineering business units, engineering business units rate CSF4 (design review with all stakeholders) higher. This may imply that engineering projects involve more stakeholders than non-engineering projects, and are therefore more dependent on review by all stakeholders during the design phase to ensure project success. All the other nine CSFs are equally critical in the view of the engineering and non-engineering business units.

Evaluating the two groups in size of business unit, CFS3 (functional manager support), CSF7 (project manager communication skill), and CSF9 (monthly project review) are considered to be more critical for large business units (more than 1,000 employees). In other words, for large business units, both functional and project managers are vital. Moreover, frequent (monthly) project reviews are necessary to ensure the success of managing multiple projects.

In Table 9, employees with fewer years of project experience (less than 10 years) rated two CSFs to be more important than did employees with more than 10 years of project experience: CSF5 (skill transfer to new teams) and CSF10 (emails). It is clear that, when employees are inexperienced, skill transfer becomes important to ensure the quality of project outcomes. If one compares the scores for the two communication CSFs - monthly project review (CSF9) and email (CSF10) - it is clear that monthly project review is considered to be equally critical for both independent groups. However, communication using emails is regarded to be more critical for employees with less than 10 years of project experience. In other words, besides personal face-to-face communications via monthly project reviews, regular digital communication via emails is important for inexperienced employees so that they can exchange their updated progress on a more frequent basis using email. All CSFs are equally critical, whichever sources are used to initiate the projects, apart from CSF10 (emails). That is, when projects are initiated by a single source, 
communication via email is more critical than in projects initiated by multiple sources. Perhaps it is because, when projects are initiated by a single source - i.e. by marketing, technical staff, or top management - incremental innovative activities are performed (e.g., improving the existing technology) and codified information is exchanged (often via digital communications such as email).

\begin{tabular}{|c|c|c|c|c|c|c|c|c|c|c|}
\hline \multirow{3}{*}{ CSF } & \multicolumn{5}{|c|}{$\begin{array}{l}\text { Employee experience } \\
\text { Group 0: less than } 10 \text { years } \\
\text { Group 1: more than } 10 \text { years }\end{array}$} & \multicolumn{5}{|c|}{$\begin{array}{c}\text { Source of project } \\
\text { Group 0: single source } \\
\text { Group 1: multiple sources }\end{array}$} \\
\hline & \multicolumn{2}{|c|}{$\begin{array}{l}\text { Group } 0 \\
(\mathrm{~N}=133)\end{array}$} & \multicolumn{2}{|c|}{$\begin{array}{c}\text { Group 1 } \\
(\mathrm{N}=117)\end{array}$} & \multirow{2}{*}{$\begin{array}{c}\text { Mean } \\
\text { difference } \\
\text { t-test }^{\mathrm{a}} \\
\text { p-value }^{\mathrm{b}}\end{array}$} & \multicolumn{2}{|c|}{$\begin{array}{l}\text { Group } 0 \\
(\mathrm{~N}=103)\end{array}$} & \multicolumn{2}{|c|}{$\begin{array}{c}\text { Group 1 } \\
(\mathrm{N}=147)\end{array}$} & \multirow{2}{*}{$\begin{array}{c}\text { Mean } \\
\text { difference } \\
\text { t-test }^{\mathrm{a}} \\
\text { p-value }^{\mathrm{b}}\end{array}$} \\
\hline & Mean & SD & Mean & SD & & Mean & SD & Mean & SD & \\
\hline CSF1 & 4.28 & 0.844 & 4.38 & 0.708 & -0.106 & 4.32 & 0.795 & 4.33 & 0.780 & -0.008 \\
\hline CSF2 & 4.27 & 0.763 & 4.31 & 0.640 & -0.040 & 4.33 & 0.746 & 4,26 & 0.679 & 0.066 \\
\hline CSF3 & 4.06 & 0.856 & 4.20 & 0.819 & -0.140 & 4.05 & 0.879 & 4.18 & 0.8 & -0.130 \\
\hline CSF4 & 4.13 & 0.826 & 4.06 & 0.714 & 0.067 & 4.12 & 0.844 & 4.08 & 0.726 & 0.035 \\
\hline CSF5 & & 0.842 & 3.94 & 0.705 & $0.204^{*}$ & 4.16 & 0.869 & 3.98 & 0.718 & 0.181 \\
\hline CSF6 & & 0.809 & 4.07 & 0.716 & -0.063 & 4.01 & 0.880 & 4.06 & 0.677 & -0.046 \\
\hline CSF7 & 4.01 & 0.809 & 3.91 & 0.732 & 0.094 & 3.98 & 0.816 & 3.95 & 0.746 & 0.029 \\
\hline CSF8 & 3.97 & 0.887 & 3.91 & 0.890 & 0.060 & 4.04 & 0.843 & 3.87 & 0.914 & 0.166 \\
\hline CSF9 & 3.83 & 0.986 & 3.9 & 0.8 & -0.116 & 3.75 & 0.968 & 3.9 & 0.859 & -0.229 \\
\hline CFS10 & 4.05 & 0.758 & 3.61 & 0.800 & $0.441^{*}$ & 4.11 & 0.747 & 3.66 & 0.799 & $0.445^{*}$ \\
\hline
\end{tabular}

a. Mean difference between two groups

b. Significance at $5 \%$ level ( $p$-value $\varangle$.05)

* mean difference is statistically significant at $p \varangle 0.05$

\section{Table 9: Independent t-test: Employee experience and source of project}

When projects are initiated by multiple sources (i.e. combinations of the above-mentioned sources), more parties are involved due to the complexity of the projects, and thus communications via email is less important, because this form of communication cannot facilitate the tacit knowledge that is often needed for innovations.

In order to extend the conventional CSFs model developed earlier (Table 7), demographic dimensions are added by summarising the significant group differences found in Tables 8 and 9. The extended CSFs model for multiple projects in TFR is given in Table 10.

\section{CONCLUSIONS AND RECOMMENDATIONS}

The aim of this study was to explore critical success factors for multiple project success in Transnet Freight Rail. It is argued that project participants may have different viewpoints about the success criteria for project success. In other words, a success factor may be seen as more important by a certain type of project participant but not by another. Thus this research proposed an extension of the conventional Critical Success Factors (CSFs) model by adding demographic characteristics. In this section, the most important findings are summarised and discussed, followed by a discussion of the limitations of this study and recommendations for future study directions.

\subsection{Main findings and implications}

After carefully describing the theoretical and methodological background of the study, the empirical analyses consisted of two parts. In the first part, the focus was on identifying ten critical success factors for multiple project success. The findings show that the emphasis lies on the people factors category, which includes five out of the ten CSFs.

Moreover, the two most important CSFs are also in this category. The top CSF is 'selection of an adequate team to run the project' since, in a multi-project environment, a project participant may be involved in several projects at the same time. 


\begin{tabular}{|c|c|c|}
\hline Focus areas & Critical success factor (Rank) & $\begin{array}{l}\text { Significant criticality to } \\
\text { demographic characteristics }\end{array}$ \\
\hline $\begin{array}{l}\text { Organisational } \\
\text { structure }\end{array}$ & $\begin{array}{l}\text { Encouraging functional managers' support } \\
\text { (Rank 3) }\end{array}$ & $\begin{array}{l}\text { Business unit with more than } \\
1,000 \text { employees }\end{array}$ \\
\hline \multirow[t]{2}{*}{$\begin{array}{l}\text { Communication } \\
\text { type }\end{array}$} & Monthly review meetings (Rank 9) & $\begin{array}{l}\text { Business unit with more than } \\
1,000 \text { employees }\end{array}$ \\
\hline & $\begin{array}{l}\text { Using email as a type of communication during } \\
\text { project life (Rank 10) }\end{array}$ & $\begin{array}{l}\text { Business unit with average } \\
\text { employee experience of less } \\
\text { than } 10 \text { years; } \\
\text { Projects initiated by a single } \\
\text { source }\end{array}$ \\
\hline \multirow[t]{5}{*}{$\begin{array}{l}\text { People } \\
\text { characteristics }\end{array}$} & $\begin{array}{l}\text { Selection of an adequate team to run the } \\
\text { project (Rank 1) }\end{array}$ & $\begin{array}{l}\text { Same criticality for any } \\
\text { demographic characteristic }\end{array}$ \\
\hline & $\begin{array}{l}\text { Commitment of the project manager, project } \\
\text { team, and top management to the project } \\
\text { (Rank 2) }\end{array}$ & $\begin{array}{l}\text { Same criticality for any } \\
\text { demographic characteristic }\end{array}$ \\
\hline & $\begin{array}{l}\text { Developing knowledge of new team members } \\
\text { on the organisation (Rank 5) }\end{array}$ & $\begin{array}{l}\text { Employee experience of less } \\
\text { than } 10 \text { years }\end{array}$ \\
\hline & $\begin{array}{l}\text { Importance of a project manager's } \\
\text { communication skills (Rank 7) }\end{array}$ & $\begin{array}{l}\text { Business unit with more than } \\
1,000 \text { employees }\end{array}$ \\
\hline & $\begin{array}{l}\text { The competence of the project leader and } \\
\text { project team in the field where the project is } \\
\text { conducted (Rank } 8 \text { ) }\end{array}$ & $\begin{array}{l}\text { Same criticality for any } \\
\text { demographic characteristic }\end{array}$ \\
\hline $\begin{array}{l}\text { Type of } \\
\text { project }\end{array}$ & $\begin{array}{l}\text { Design reviews with all stakeholders involved } \\
\text { (Rank 4) }\end{array}$ & Engineering business units \\
\hline $\begin{array}{l}\text { Type of } \\
\text { environment }\end{array}$ & $\begin{array}{l}\text { Economic standing of the organisation in } \\
\text { funding large projects (Rank 6) }\end{array}$ & $\begin{array}{l}\text { Same criticality for any } \\
\text { demographic characteristic }\end{array}$ \\
\hline
\end{tabular}

\section{Table 10: Extended CSFs model for multiple projects in TFR}

For example, an inadequate person who cannot accomplish Project $\mathrm{A}$ on time may have an adverse effect on Project B, and so both projects may face late project deliveries. Selection of adequate team implies that a focus on (human) resource scheduling when running multiple projects will ensure overall success.

The second top CSFs is 'commitment of the project manager, project team, and top management to the project'. When running multiple projects, the level of commitment may vary across projects. In other words, top management may see certain projects to be more important than the others, and thus are more committed to these projects. However, the project managers who are responsible for managing the projects assigned to them by the top management may see things otherwise. Similarly, project team members may share different views and commitments. This finding suggests that a common vision be established within the organisation regarding prioritising multiple projects.

The next important category is communication factors, with two CSFs. In the multi-project environment, communication is vital for the effective and efficient transfer of information and knowledge. Two types of communication are regarded as critical: monthly project review meetings, regarded in this study as a direct way of communication in which all the project participants review the projects face-to-face; and emails, seen as an indirect way of communication. The findings suggest that in a multi-project environment, both direct and indirect communication methods are necessary. Since the projects are R\&D related in TFR, knowledge as a resource plays an important role in innovation. Direct face-to-face communications are necessary for transferring tacit aspects of knowledge (e.g. learning by doing), associated with new innovations in strategic projects assigned by the TFR's top management. On the other hand, implicit knowledge (e.g. design drawings) can be sent via email. This type of knowledge is associated with incremental innovations in the minor projects requested by customers.

When evaluating the second part of the analysis, where the authors used independent sample t-tests to identify group mean differences, it is recommended to take two demographic characteristics into consideration when managing multiple projects. The first important demographic characteristic is the size of business units participating in multiple 
projects. In the multi-project environment, if the majority of business units are large (more than 1,000 employees), the following factors are important:

- encouraging functional managers' support

- a project manager's communication skills

- monthly review meetings.

The second important demographic characteristic is the project participants' years of experience. When the majority of project participants involved in multiple projects have only a few years of project experience (less than 10 years), it is recommended that the following factors be taken into consideration:

- using email as a type of communication during the project life

- developing knowledge of new team members in the organisation.

Communication via email is the only CSF that is importance to two demographic characteristics: employees having less than 10 years' experience, and a project initiated by a single source. This result may arise because multiple projects involving less-experienced employees (project participants) or initiated by a single source (e.g. only by marketing, technical staff, or top management) ask for more codified knowledge (information that can be presented in text or drawings) that is easier to transfer digitally (by email). Such projects may be seen to have more incremental aspects of $R \& D$, in that only minor changes to the existing design are needed.

The complete CSF model (with an extension for the demographic dimension) for the success of multiple projects is shown in Table 10 in the previous section. This model highlights the focus areas for Transnet Freight Rail when managing multiple projects, and serves as a guideline for the organisation's future success. However, there are certain limitations to this study, discussed in the next section.

\subsection{Limitations and direction for future research}

Although this research reveals certain critical success factors for multiple projects, certain limitations remain. First, these findings are limited to the case of Transnet Freight Rail, one of the biggest projects-based businesses in South Africa. Similar studies should be done with other projects-based businesses in South Africa. Although it is believed that success factors cannot be generalised for all projects, CSFs identified in other cases may help to identify possible focus areas (such as the classification of success factors) for South Africa as representative of an emerging economy. Second, this study has only focused on the identification of CSFs, and not on the relationships among these factors. A factor may have a positive or a negative influence on other factors. Exploring such relationships may contribute further to the literature on success factors in multi-project environments. Last, the CSFs developed in this study are associated with an overview of multiple projects, not with specific phases of a project. If one revisits Figure 1 , it shows that at $t_{2}$, four projects are run concurrently at various life cycle phases. Moreover, at $t_{2}$, one specific factor may have an impact on the success of phase 1 (e.g., a clear project objective is essential during the project design phase) of Project 2, but may not have a major impact on phase 4 of Project 1 (e.g., a clear project objective is less important in the final stage of project).

\section{REFERENCES}

[1] Chan, A.P.C., Scott, D. \& Chan, A.P.L. 2004. Factors affecting the success of a construction project, J ournal of Construction Engineering and Management, 130(1), pp. 153-155.

[2] Dvir, D., Lipovetsky, S., Shenhar, A. \& Tishler, A. 1998. In search of project classification: A non-universal approach to project success factors, Research Policy, 27(9), pp. 915-935.

[3] Engwall, M. \& Jerbrant, A. 2003. The resource allocation syndrome: The prime challenge of multi-project management? International J ournal of Project Management, 21(6), pp. 403-409.

[4] Steyn, H., Basson, G., Carruthers, M., du Plessis, Y., Kruger, D., Pienaar, J., ProzeskyKuschke, B., Van Eck, S. \& Visser, K. 2007. Project management: A multi-disciplinary approach, $2^{\text {nd }}$ ed. FPM Publishing, South Africa.

[5] Van Der Merwe, A.P. 1997. Multi-project management - organizational structure and control, International J ournal of Project Management, 15(4), pp. 223-233. 
[6] Thompson, B.P., Anderson, S.D, Russell, J.R. \& Hanna, A.S. 2002. Guidelines for warranty contracting for highway construction, J ournal of Management in Engineering, 18(3), pp. 129-137.

[7] Elonen, S. \& Artto, K.A. 2003. Problems in managing internal development projects in multiproject environments, International J ournal of Project Management, 21(6), pp. 395-402.

[8] Abdullan, A.M. \& Vickridge, I.G. 1999. Best practice for multi-project management in the construction industry. In: Proceedings COBRA. RICS Foundation, pp. 169-179.

[9] Kerzner, H. 1998. Project management: A systems approach to planning, scheduling, and controlling, $6^{\text {th }}$ ed. J ohn Wiley $\&$ Sons Inc, Canada.

[10] Nicholas J.M. \& Steyn, H. 2008. Project management or business, engineering and technology: Principles and practice. Elsevier, Canada.

[11] Meredith, J.R. \& Mantel, J r., S.J . 2006. Project management: A managerial approach. $6^{\text {th }}$ ed. J ohn Wiley \& Sons (Asia) Pte Ltd., USA.

[12] Wiley V.D., Deckro, R.F. \& J ackson, J.A. 1998. Optimization analysis for design and planning of multi-project portfolios, European J ournal of Operational Research, 107(2), pp. 492-506.

[13] Lambrechts, O., Demeulemeester, E. \& Herroelen, W. 2008. Proactive and reactive strategies for resource-constrained project scheduling with uncertain resources availabilities, Journal of Scheduling, 11(2), pp. 121-136.

[14] J arboui, B., Damak, N., Siarry, P. \& Rebai, A. 2008. A combinatorial particle swarm optimization for solving multi-mode resource-constrained project scheduling problems. Applied Mathematics and Computation, 195(1), pp. 299-308.

[15] Kim, K., Yun, Y., Yoon, J., Gen, M. \& Yamazaki, G. 2005. Hybrid genetic algorithm with adaptive abilities for resource-constrained multiple project scheduling, Computers in Industry, 56(2), pp. $143-160$

[16] De Wit A. 1988. Measurement of project success, International J ournal of Project Management, 6(3), pp. 165-170.

[17] Daniel, D.R. 1961. Management information crisis, Harvard Business Review, 39, pp. 111-121.

[18] Rockart, J. 1979. Chief executives define their own data needs, Harvard Business Review, 57(2), pp. 81-93.

[19] Bullen, C.V. 1995. Re-examining productivity critical success factors, Information System Management, 12, pp. 13-18.

[20] Tishler, A., Dvir, D., Shenhar, A. \& Lipovetsky, S. 1996. Identifying critical success factors in defense development projects: A multivariate analysis, Technological Forecasting \& Social Change, 51(2), pp. 151-172.

[21] Aksorn, T. \& Hadikusumo, B.H.W. 2008. Critical success factors influencing safety program performance in Thai construction projects, Safety Science, 46(4), pp. 709-727.

[22] Chow, T. \& Cao, D.-B. 2008. A survey study of critical success factors in agile software projects, The J ournal of Systems and Software, 81(6), pp. 961-971.

[23] Zhao, Z.-Y., Zuo, J., Zillante, G. \& Wang X.-W. 2010. Critical success factors for BOT electric power projects in China: Thermal power versus wind power, Renewable Energy, 35(6), pp. 12831291.

[24] Fortune, J . \& White, D. 2006. Framing of project critical success factors by a systems model, International J ournal of Project Management, 24(1), pp. 53-65.

[25] White, D. \& Fortune, J., 2002. Current practice in project management - an empirical study, International J ournal of Project Management, 20(1), pp. 1-11.

[26] Dvir, D., Lipovetsky, S., Shenhar, A. \& Tishler, A., 1994. Identifying managerial variables critical to the success of projects: Multivariate analysis of large data sets, Israel Institute of Business Research, Working Paper No. 6/94, Faculty of Management, Tel Aviv University.

[27] Belassi, W. 1996. A new framework for determining critical success/ failure factors in projects, International J ournal of Project Management, 14(3), pp. 141-151.

[28] Balachandra, R. \& Friar, J.H. 1997. Factors for success in R\&D projects and new product innovation: A contextual framework, IEEE Transactions on Engineering Management, 44(3), pp. 276-284. 